\title{
FEDERAL PERCEPTIONS AND POLICY VERSUS VIRGIN ISLANDS REALITY
}

\author{
Jerome L. McElroy and Klaus de Albuquerque*
}

Ineffective economic policy can derive from a variety of well-documented causes: inappropriate planning models (Seers, 1963; Streeten, 1966), weak administrative machinery (A. Lewis, 1959), lack of popular participation (Waterston, 1974), and conflict over goals (Tinbergen, 1967). However, a major source of policy disagreement is often insufficiently recognized, especially in cases where many decisionmaking levels and actors are involved. It is the different perceptions among the actors concerning the structure and behavior of the subject economy. Different views of the nature of the system can easily give rise to divergent assessments of the goals achieveable, as well as different identifications of bottlenecks and subsequently different policy solutions.

A striking contemporary illustration is the clash of different economic perceptions in the development literature (Henriot, 1979). On the one hand, earlier primary Western theorists conceptualized LDCs as relatively primitive self-contained systems suffering from isolation and a self-reinforcing set of basically internal supply and demand deficiencies (A. Lewis, 1954; Rostow, 1960; Bauer, 1981). On the other hand, third world economists of the dependency school trace present poverty to past colonial roots, i.e., to the external links which have resulted in an unequal pattern of center-periphery trade, pricing, and capital flows, inappropriate imported technology, multinational control, and so on (Beckford, 1972; Amin, 1974, 1976; Frank, 1979). These divergent economic perceptions have spawned widely disparate remedies. In the internal supply and demand case remedies include improving the market mechanism through appropriate incentives, a critical minimum of resource mobilization, and industrialization. In the dependency case remedies include a wholesale restructuring of international exchange, aid, and investment patterns and commodity price indexation to release the external barriers which constrain LDC progress (Ul Haq, 1976; Blake and Walters, 1983). ${ }^{1}$

There is a long-standing tradition of discrepant perceptions of development problems and remedies in many present and former colonial areas. Thus it is not surprising that conflicts have often infested the coordination of colonial economic policy since these arrangements generally involve two distinct groups separated by distance, experience, context, and decision-making authority. Such has been the case in the United States Virgin Islands (USVI). Persistent disagreements over the nature of the economy between U.S. federal and local territorial officials have hindered policy consensus and implementation. The situation has been further exacerbated because of the unique status of the USVI as an unincorporated U.S. territory. This status is not readily categorized and, in fact, is conducive to the formation of different perceptions of economic behavior and different yardsticks of performance. As a final complication, the distribution of responsibility of territorial affairs in the USVI has not always been clearly allocated among the federal agencies involved. This has produced at times piecemeal approaches to chronic problems.

As a result of these influences, perceptual distortions abound. Visiting federal officials, mindful of the heavy inflow of U.S. aid, are perplexed at the Islands' deteriorating services and persistent deficits, and often locate the problem in inept local administration (Boyer, 1983: 356-62). On the other hand, USVI officials focus almost exlcusively on the American economy and federal legislative and executive actions 
underlining their long-held belief that the center of insular decisionmaking and economic performance lies more in Washington than in the capital, Charlotte Amalie (Lewis, 1972: 320). Less partisan academic observers often situate the territory in the context of an independent developing country and stress its limited resources, markets, and internal linkages (Miller, 1979: 4).

Section One of this essay briefly explores the role that such differing perceptions have played in the broad conduct of USVI economic policy. Emphasis is placed on the implicit and often mistaken federal characterization of the territory as a relatively autonomous, if undeveloped, entity with a measurable potential for a viable and independent economic life of its own. Section Two suggests a more empirically sound basis for agreement in the conception of the insular economy as a tightly integrated regional subsystem of the U.S. which draws its vitality from its responsiveness to national forces. This view is corroborated by an examination of the USVI impacts stemming from general and specific U.S. economic policies. Section Three reviews some of the more obvious policy directions flowing from such a satellite formulation of territorial economic behavior and discusses some implications of the USVI experience for U.S. policy in the wider Caribbean.

\section{I}

The U.S. purchase of the formerly Danish Virgins in 1917 ratified politically in the broad sense what had long since been economic reality, i.e., close incorporation of the Islands into the American commercial network. As early as 1830, the U.S. had become the territory's dominant trading partner as supplier of essential foodstuffs and manufactures and as a major outlet for export sugar and molasses (Dookhan, 1974: 102). However, this economic nexus was explicitly deemphasized by the amorphous legal definition of nonincorporation affixed to the Islands, a status which connoted no special present or future process of viable socio-economic integration. ${ }^{2}$ This was in direct contrast to the traditional doctrine of incorporation which provided for an orderly progression of national assimilation culminating in statehood, and according to Boyer (1983: 103), "clearly contrary to the principle of equality set forth in the Declaration of Independence."

This ambiguous legal definition led to the continuation of special Danish privileges like duty-free status and exemption from U.S. cabotage laws and to the grouping of the Virgins with the other similarlydefined far-flung possessions of Puerto Rico and the Philippines. Thus took root the perception of the territorial economy as primarily a sui generis system with an independent viability functioning in relative isolation from the U.S. mainstream. This perception was clearly in line with official U.S. policy articulated by President Roosevelt:

We hope to do for them what has never been done for any people of the tropics - to make them fit for self-govenment after the fashion of a really free nation. (Creque, 1968: 61)

On the other hand, this view was contrary to the Islanders' expectation that closer U.S. affiliation would expand opportunity and access to private capital. Although inter-island disputes fostered a focus on insular (St. Thomas versus St. Croix) over territorial interests, local leaders were unanimous in their recognition of the overriding significance of national forces and legislation on their economic destiny:

St. Croix was always concerned with the drastic economic effects of Prohibition upon its rum and sugar industries, while St.

Thomas was more concerned with preventing the application of U.S. coastwise shipping legislation to its merchantile interests.

(Lewis, 1972: 65)

During the Depression era, USVI dependence on national activity was largely ignored as federal policy embarked on a massive revitalization scheme involving tourist promotion, infrastructure rehabilitation, domestic agriculture and cottage industries, and a revival of sugar. In retrospect, this New Deal experiment anticipated the big-push programs initiated by development planners in the 1950s and 1960s to break through the poverty syndrome. Likewise, the USVI strategy was premised on the same false notion implicit in these more recent efforts that a critical quantum of resource assistance was sufficient to propel the economy across the threshold into its own pattern of self-sustained growth. This view was stated enthusiastically in the Brown Report, the blueprint for the policy:

... sufficient to do energetically at once the things that are necessary to bring about improved conditions and thus make it possible, by helping Virgin Islanders to help themselves, to reduce gradually the federal aid with the ultimate result of making the islands entirely self-supporting. (Lewis, 1972: 69)

In addition, the plan contained no clear recognition of the role played by overall U.S. behavior and 
national economic policy in the commercial life of the territory. Yet, this "self-supporting" conception did correspond to the popular federal perception that USVI development problems were essentially internal. The list of these dysfunctions circulating in Washington included: restricted opportunity due to monopoly market control, inter-island rivalry, unimaginative local entrepreneurs and generally inefficient management, unskilled and undisciplined labor supply, and so on.

Similar to later well-intentioned but misguided development schemes introduced elsewhere, the program did not succeed although its impact was softened by the wartime construction of military installations. The causes of this failure were obvious: general inaccessibility of the Islands and the undeveloped tourist plant; shortage of cheap rural labor and antipathy toward farming stemming from slavery; and chronic low productivity in the highly competitive international sugar industry. In essence, the basic contradiction was that the program presumed for its own effectiveness the presence of the very resources, skills, and opportunitites it was designed to create. A further contradiction was that the explicit purpose of the policy - to enhance self-autonomy-became vitiated in practice by the growing local reliance on the steady proliferation of bureaucratic structure and public employment opportunities institutionalized in the scheme (Lewis, 1972: 83).

During the 1940s and 1950s this same perception of territorial self-sufficiency underpinned the initiatives of a succession of federally appointed governors. Although particular policies varied-civil service reform, specific grants-in-aid to overcome bottlenecks, fiscal austerity-the underlying emphasis was consistently to reduce dependence on the federal treasury and to foster economic self-determination. This stance was at variance with the position of territorial officials "who had come to believe that the most important function of the governor was to lobby for increased federal appropriations" (Lewis, 1972: 109). Moreover, there was scant appreciation of the special sensitivity of insular activity to national policy. As evidence, apart from the continued promotion of domestic and export agriculture despite obvious signs of its secular deterioration, ${ }^{3}$ no contingency planning was developed to compensate for the significant reduction in employment that followed the cessation of war. Likewise, there was little anticipation that peacetime conversion on the mainland would cause a drastic 70 percent drop in rum exports to the U.S. in the mid 1940 s, a lesson that should have been learned from the Prohibition experience. ${ }^{4}$

Part of this oversight was undoubtedly due to the federal belief that the territorial economy was sufficiently buttressed against exogenous shocks by a structure of special privileges that functioned like a system of built-in stabilizers. These included the traditional Danish free-port status, the Jones Act exemption, the U.S. progressive income tax system, the rum matching fund, duty-free entry into the U.S. of insular manufactures, and generous concessions for tourists purchasing gifts and liquor in the Islands. ${ }^{5}$ Over-confidence in these advantages blunted policymakers' recognition that the operation of these same provisions was as cyclically sensitive to the vagaries of U.S. behavior and policy as the rest of the insular system, and hence that such concessions were not only ineffective as automatic stabilizers, but also, given the assumed income elasticities of the relevant products/services involved, possibly destabilizing.

In this connection, another fundamental policy contradiction is apparent: heavy reliance on these automatic mechanisms was starkly inconsistent with the traditional federal perception of the insular economy as a relatively independent entity. This conceptualization by definition would require considerably more local autonomy than allowed by territorial status as well as a specific array of discretionary policy functions consonant with achieving countercyclical stability. Such prerogatives would include local control over taxes, immigration, minimum wages application, ability to conduct independent commercial policy, authority to unbalance the budget and to determine the value of the exchange rate. Because the above functions are legally vested exclusively in the federal government, the sharp disjunction arose between the perception of the island economy with a quasi-independent life of its own, and on the other side the lack of local control over the appropriate policy handles to maintain that life against external events.

The 1960s witnessed an unprecedented boom in tourism, export manufactures, and construction activity (see Table 1). Both external and internal factors produced this turnaround. External factors included: the U.S. embargo of Cuba which deflected American tourists and capital to the Islands, U.S. prosperity-the territory's prime market—jet travel expansion, and generally depressed conditions in 
the nearby Caribbean dependencies (McElroy, 1974). This last insured an elastic low-cost labor supply to meet the labor-intensive demands of the tourism and construction sectors. The internal factors involved the aggressive implementation of a broad array of growth policies by local officials. These included: the phase-out of commercial sugar, creation of an industrial incentive program, and successful representation in Washington which resulted in large inflows of federal assistance which helped to create a costly new infrastructure to support the large-scale modernization underway.

Federal policy was passively supportive of these local initiatives, maintaining the quite vital temporary (nonimmigrant) foreign worker program as well as other existing concessions. It was a time of rapid transition marked by an intensification of the centuries-old process of territorial integration into the national economy. Through these legislated concessions, the Islands were accorded access to expanding U.S. markets and elastic supplies of capital, technology, and infrastructure to mobilize the labor pool readily available in the region. It was precisely the external reach and cyclical sensitivity of these privileges in conjuction with U.S. political affiliation which enabled the territory to maximally exploit the favorable growth environment occurring outside. In the process, the economic future of the USVI became increasingly more dependent upon the mainland. The tourism base became pervasive at the same time that new ties were forged with national travel, financial, and transport interests. Temporary foreign and seasonal U.S. workers became permanent contingents in the local labor force. A host of federal social service and regulatory programs were institutionalized. Finally, heavy manufacturing activity (petroleum and alumina refining) tied the territory inextricably into the global energy and raw materials markets.

The relatively passive federal policy posture of the 1960s gave way to a more active concern with territorial affairs during the inflationary and recession-ridden 1970s (see Table 1). Escalating insular deficits necessitating increasingly large Congressional compensatory appropriations generated a federal preoccupation with local financial administration. The question of local fiscal responsibility first raised

TABLE 1

Major United States Virgin Islands Economic Indicators: 1960-82

\begin{tabular}{|c|c|c|c|c|c|c|c|c|}
\hline Year & $\begin{array}{c}\text { GTP1 }^{1} \\
\text { (millions) }\end{array}$ & $\begin{array}{c}\text { Total } \\
\text { Imports } \\
\text { (millions) }\end{array}$ & $\begin{array}{c}\text { Total } \\
\text { Exports } \\
\text { (millions) }\end{array}$ & $\begin{array}{l}\text { Electricity } \\
\text { Production }^{2} \\
\text { (mill. kwt) }\end{array}$ & $\begin{array}{l}\text { Value of } \\
\text { Construc- } \\
\text { tion } \\
\text { Permits } \\
\text { (millions) }\end{array}$ & $\begin{array}{l}\text { Number } \\
\text { Business } \\
\text { Licenses }^{2}\end{array}$ & $\begin{array}{l}\text { Total } \\
\text { Labor } \\
\text { Force }\end{array}$ & $\begin{array}{l}\text { Unem- } \\
\text { ployment } \\
\text { Rate (\%) }\end{array}$ \\
\hline 1960 & 25.0 & 42.3 & 8.4 & 34.3 & 5.2 & 2,113 & 11,228 & 3.4 \\
\hline 1965 & 68.7 & 118.7 & NA & 90.5 & 27.2 & 3,735 & 21,018 & 0.9 \\
\hline 1970 & 242.3 & 400.6 & 244.5 & 255.8 & 80.2 & 6,956 & 35,580 & 1.3 \\
\hline 1971 & 267.2 & 551.6 & 325.8 & 305.3 & 71.3 & 9,258 & 36,400 & 1.4 \\
\hline 1972 & 304.5 & 596.2 & 400.9 & 348.0 & 68.5 & 10,298 & 36,683 & 2.0 \\
\hline 1973 & 294.9 & 850.6 & 611.9 & 384.0 & 46.2 & 10,981 & 37,420 & 4.6 \\
\hline 1974 & 295.0 & $2,220.4$ & $1,658.9$ & 394.2 & 36.2 & 9,027 & 38,910 & 5.5 \\
\hline 1975 & 295.7 & $2,196.3$ & $1,934.5$ & 397.7 & 28.2 & 9,226 & 36,142 & 8.0 \\
\hline 1976 & 299.4 & $2,685.3$ & $2,009.8$ & 397.4 & 30.7 & 8,278 & 36,385 & 10.8 \\
\hline 1977 & 299.2 & $2,976.7$ & $2,613.5$ & 413.4 & 43.2 & 8,899 & 37,407 & 7.9 \\
\hline 1978 & 297.2 & $3,171.1$ & $2,542.4$ & 426.0 & 41.3 & 9,235 & 39,520 & 6.4 \\
\hline 1979 & NA & $3,773.5$ & $3,088.1$ & 445.7 & 73.1 & 11,769 & 41,630 & 5.6 \\
\hline 1980 & NA & $4,919.5$ & $4,315.1$ & 448.7 & 103.1 & 10,660 & 43,130 & 6.1 \\
\hline 1981 & NA & $5,013.6$ & $5,068.2$ & 443.9 & 62.7 & 10,384 & 43,210 & 6.5 \\
\hline 1982 & NA & $5,261.3$ & $5,961.1$ & 450.9 & 58.4 & 10,093 & 43,550 & 7.8 \\
\hline 1983 & NA & $4,668.7$ & $3,649.2$ & 466.1 & 69.4 & 10,185 & 43,260 & 8.3 \\
\hline
\end{tabular}

Source: de Albuquerque and McElroy (1983a), p. 641, Table 2.

Notes: 1In real terms for $1970-78$

${ }^{2}$ Data for fiscal year 
by the resident U.S. Comptroller (1978) later became the subject of studies by both the Department of Interior (Miller, 1979) and Treasury (1979) and eventually culminated in President Carter's declaration of a comprehensive new policy embracing all U.S. territories (February, 1980). While USVI officials welcomed most of the new proposals-encouragement towards greater political autonomy, increased technical assistance, reduced matching grant requirements, grant consolidation-there was considerable opposition to the proposed IRS takeover of territorial tax collections.

Analysis of this program, now defunct for lack of funding, reveals several flaws and inconsistencies. First is the highly significant omission of the close linkage of USVI economic behavior to U.S. performance. This is paramount to neglecting the most important drive in the territorial economy. This oversight was undoubtedly due to the historical practice of lumping the USVI with the Pacific territories (Guam, American Samoa, Northern Marianas) and presuming that political similarities override economic differences. Second, implicit in this grouping was the "outlying possession" perception of the USVI as a relatively isolated economy with its own internal dynamic:

... we in Washington have an obligation to protect and nurture the unique cultures and fragile economies of these islands, which are so distinct from the rest of the Nation (italics added) in terms of history, geography, economic potential, tradition, and ethnic composition. (Carter, 1980: 2)

Such a perception is at variance with the integration which has occurred since 1960, since the one aspect which distinguishes the USVI from the Pacific territories is precisely its geographic proximity to and close economic affiliation with the U.S.

A further anomaly involves the IRS takeover proposal so bitterly contested in the Islands. Ironically, the justification for this policy was the "comparative" evidence set forth in the Interior and Treasury studies that the revenue achievement of the larger territories (USVI and Guam) was significantly below the U.S. norm during the mid-1970s. Yet, as USVI officials argued, ${ }^{6}$ using this U.S. yardstick was not only flagrantly at variance with the "outlying possession" perception that informed the overall policy thrust of the declaration, i.e., economic and political self-determination, but also explicitly contrary to stated federal expectations of territorial economic performance:

Our goal should be to recognize these distinctions as assets rather than to expect the territories to conform to practices and policies designed for the States and often inapplicable to insular areas. (Carter, 1980: 2)

As a corrolary, the proposed takeover itself and related provisions to dismantle certain aspects of the USVI's income tax abatement program were more compatible with the state-like view of the absence of such special concessions than the politically appealing "so distinct" perception.

Renewed threats to territorial concessions have occurred under the Reagan Administration. These include: (1) a tax option proposal, i.e., either a U.S. takeover or territorial tax autonomy, rejected in the Islands; ${ }^{7}$ (2) judicial defeat of a request for the return of federal excise taxes on territorial petroleum products shipped to the U.S.; and (3) the introduction of Congressional legislation to repeal the territory's exemption from U.S. cabotage laws. ${ }^{8}$ This harder line orientation has stemmed primarily from the administration's private sector pro-market policy rather than from any deviation in territorial perception. In response to mounting USVI charges of federal inaction and neglect, the top U.S. territorial official reported:

The Reagan administration does have a territorial policy. It is to make the territories self-sufficient, self-reliant, and selfespecting. . .9

In summary, this continuing conflict between federal perception and economic reality justifies the need for renewed examination of the underlying nature of the territorial economy as a preliminary step in constructing a more appropriate and thereby more effective policy framework.

\section{II}

It is clear from an examination of the evidence that the modern USVI economy functions as a satellite of the U.S. economy. For example, with respect to structure, the territory's major exports of tourism, petroleum, rum, and light industrials (watches, textiles, pharmaceuticals) sell almost exclusively in U.S. markets. Between 1970-79, U.S. exports as a percentage of total USVI exports (excluding petroleum and alumina products) averaged 89 percent. ${ }^{10}$ In addition, U.S. citizens comprise above 85 percent of all tourists. Over the same period, the U.S. share of USVI imports was 72 percent.

The public sector is also closely tied to the U.S. Because of the balanced budget requirement, expenditures are controlled by revenues. Revenues are based primarily on the same progessive income tax 
structure obtaining in the U.S. and a sizeable inflow of external federal funding including grants-inaid, special appropriations, the rum fund, bond sales, and others. Together these external sources, depending on how they are defined, ${ }^{11}$ make up roughly 30-60 percent of the total resources available for public expenditure. Historically, most infrastructure has been funded primarily through federal outlays while large-scale private development projects have also traditionally been financed by off-island U.S. investors.

The Islands are almost totally reliant on mainland suppliers for consumption goods and intermediate products (excluding crude oil, bauxite, and light industrial components). Consequently, insular tastes and work patterns are quite similar to U.S. behavior, with minor differences readily explained by distinctive island topographic, climatic, and cultural features (McElroy and Caines, 1980). Likewise, U.S. dominance is also reflected in the decisionmaking patterns of the financial, travel, and transport industries because these sectors are multinational branch subsidiaries of U.S. parent companies. For example, the territorial financial system, under the same regulatory authority of the Federal Reserve, corresponds closely to that of the mainland with interest and mortage rates and deposits moving in unison across the two jurisdictions (Rozynski, 1981).

With respect to overall behavior, the studies available demonstrate extremely close association with U.S. performance. For example, McElroy (1978) found that between 80-90 percent of the variation of total territorial employment during the 1960-77 period could be "explained" by the variation in U.S. real GNP with a one-year lag. ${ }^{12}$ In a follow-up study (1979) employing both annual and quarterly data, the same strong behavioral association was demonstrated. In addition, the influence of U.S. activity on individual employment sectors was analyzed. While these sectoral linkages appeared to be somewhat weaker (using quarterly data) than the annual results, as expected the responsive job clusters were precisely those most closely allied to tourism: hotel employment, retail trade, finance, and other services. Moreover, those sectors discovered to be statistically unrelated to U.S. behavior turned out to be primarily residentiary: communications and transport, utilities, territorial government.

This empirical verification of the strong U.S. connection is not surprising since the creation of the modern territorial economy as a U.S. subsystem was due to the Islands' traditional links to the U.S. strengthened markedly during the 1960 s boom because of simultaneous U.S. prosperity. Likewise, the considerably less robust performance of the insular economy during the 1970s (see Table 1) was in great part transmitted by declines in U.S. activity, most notably in 1970-71, 1974-75, and 1980-81.

A related dimension of this overall association is that the territory historically has experienced significantly larger fluctuations in behavior than the U.S. This characteristic instability the USVI shares with other highly specialized regional economies which likewise exhibit an elastic link between their export performance and the level of U.S. activity (Palmer, 1982: 152). For example, between 1960-70 USVI growth considerably outpaced U.S. expansion. In the territory, the labor force grew at an average annual rate above 15 percent while mainland employment rose less than 3 percent per year. Similarly, USVI real Gross Territorial Product (GTP) grew 10 percent per capita per year while U.S. GNP grew a modest 4-5 percent per year. On the other hand, between 1970-79 the yearly growth rates for the labor force and GTP were 1.8 percent and 2.8 percent respectively for the USVI in contrast to 2.7 percent and 3.2 percent respectively for the U.S.

This high degree of structural integration and parallel behavior can also be inferred from the impact of general and specific U.S. economic policies on the Islands. A sampling of the more obvious follows. With regard to general policies, U.S. immigration law has affected the socio-economic fabric in insular life most dramatically. Through the local application of the special Temporary Foreign Worker Program, British West Indians have become the labor base of the USVI economy. In the process, successive waves of immigrants have sharply altered the size and spatial distribution of the population, ethnic composition, levels of fertility, patterns of marriage, and so on (de Albuquerque and McElroy, 1982).

Substantial immigration has also created a cyclically sensitive employment ratchet in the labor market. During prosperity the labor force expands swelled by fresh migrant streams, and tight labor markets prevail paradoxically with a low-wage structure. On the other hand, during recessions the labor force contracts only marginally with most of the adjustment taking place through increases in unemployment and multiple part-time job-holding, decreases in saving, and reductions in remittances (Jones-Hendrickson, 1979). In addition, aliens are clustered almost exclusively in low-wage occupations establishing a 
dualism that fosters one of the most pressing internal cleavages in USVI society.

There are several other policies involving lesser but nonetheless visible local impacts. First the application of U.S. minimum wage legislation, while amply justified by the 30 percent higher-than-U.S. cost of living, has made the USVI one of the most expensive tourist destinations in the Caribbean and has blunted the industrial promotion program which is also beset by costly safety and environmental regulations.

Second, the various federal tax reduction acts implemented since 1970 have resulted in large uncompensated revenue losses to the local treasury. For example, between $1975-78$ the territory lost $\$ 22$ million or approximately 18 percent of the average total operating budget for the USVI during the same period. The impact of the Reagan tax cuts between 1981-84 is projected above $\$ 20$ million. ${ }^{13}$ Such shortfalls have led to deficits and cutbacks in services and essential capital maintenance.

Third, periodic fluctations of the U.S. dollar have generated diverse impacts. For example, while stimulating an increasing proportion of European tourists to the Islands, the steady decline (28 percent between 1973-79) in the dollar during the 1970s has, in combination with other factors, also narrowed the competitive price advantage of USVI "free-port" gift shopping against mainland and other Caribbean suppliers. This erosion occurred since most luxury merchandise sold to tourists is imported from Europe. In addition, for the same reason, earlier dollar depreciations partially explain the severe deterioration in the local textile industry. To illustrate, the value of USVI textile exports in 1971 was roughly $\$ 24$ million. From this high water mark exports declined steadily each year to a low of $\$ 5$ million in 1978 (Miller, 1979: 23-27).

Fourth, when the full force of the initial airline deregulation rate reductions was felt in 1979, local tourism experienced its best year. Average year-round hotel occupancy rates achieved an all-time high of 75 percent, and tourist air arrivals increased a remarkable 24 percent over 1978. However, because of the greater flexibility in rate setting afforded by the new regulatory regime in conjunction with escalating fuel costs and U.S. recession, declines between 1979-82 averaging 7-10 percent per year have been recorded for air arrivals, hotel occupancy, and hotel employment. ${ }^{14}$

On the other hand, favorable Congressional legislation has often fostered tourism development. For example, the 1976 Tax Reform Act allowed USVI conventioneers to deduct their expenses for tax purposes.

Fifth, Reagan budget cuts have adversely affected the territory's ability to adequately sustain certain capital projects and social service programs. To illustrate, sharp reductions in federal grants-in-aid from $\$ 296$ million in FY 1980 to $\$ 154$ million in FY 1981 (de Albuquerque and McElroy, 1983a) in combination with the severe 1980-82 recession have swollen insular welfare rolls forcing a one-third reduction in per capita payment levels (VI Daily News: 5/21/83).

Finally, at the present time territorial officials are expecting fall-out from the variety of concessions granted to their regional competitors in the recently enacted Caribbean Basin Initiative (Hughes, 1983). Two of the most damaging are perceived to be: (1) the extension of tax deductions for convention expenses, and particularly (2) the reduction of U.S. duty on bulk rum imports from basin countries. This assessment is based partly on the significantly lower wage structure and the absence of restrictions (OSHA, EPA, Wage and Hours, etc.)prevailing among USVI competitors in the region. This evidence on specific policy impacts along with the above review of national policy influences reinforces the conclusion that the insular economy is tightly integrated into the U.S. system.

\section{III}

Too often Washington has responded to Caribbean problems by hastily formulating policies based on bygone verities and perceptions "that ignore the region's dynamics" (Lowenthal, 1982: 116). This same pattern is exemplified in the USVI case. On the one hand, federal officials perceiving the Islands as isolated from the mainstream have created special programs and exclusive concessions designed ostensibly to provide short-run boosts "to enable the territories to become more self-sufficient in the long run" (Carter, 1980: 5). On the other hand, the USVI has become a mainland satellite increasingly linked to national policy initiatives usually neglected by policymakers responsible for territorial affairs.

Whatever the value biases underlying these persistent federal misperceptions (Blake and Walter, 
1983: 237), the new U.S. Caribbean Basin Initiative provides an instructive opportunity to square the federal view of the Islands' political economy with reality. In addition to better inter-agency coordination, this convergence would require the following three basics: (1) more systematic analysis of the insular economy to uncover the nature and extent of linkages with the U.S.; (2) more systematic incorporation of the USVI in national economic legislation and policy directives in contrast to the ad hoc and piecemeal inclusions of the past; and (3) more systematic communication and collaborative planning with USVI officials to narrow perceptual differences, enhance policy consensus, and produce a bank of countercyclical contingency options to soften the insular effects of U.S. fluctations.

There is some urgency in achieving this convergence in view of the U.S.'s new long-term policy commitment to the Caribbean. On the one hand, certain similarly unrealistic perceptions about these regional economies seem to inform the program. For example, President Reagan has stated that basin countries "must seek prosperity by pulling up their own economic socks instead of counting on handouts." 15 On the other hand, the countries now receiving Washington's attention, like the USVI, have become increasingly dependent since 1960 on the behavior of the U.S., now the dominant commercial partner in the region (Palmer, 1979). Moreover, the CBI concessions providing access to U.S. capital and markets should intensify this integration of the region, as USVI experience attests, and magnify the impact of national U.S. economic policies. Unless these dynamics are explicitly recognized in Washington through a more realistic perception of the area as a gradually maturing U.S. subregional economy, it is possible that the positive inducements of the stated CBI concessions may be seriously weakened or offset by the unforseen and uncorrected impacts of national initiatives.

\section{FOOTNOTES}

${ }^{1}$ For a brief analysis of this continuing polarity played out at the international policymaking level, the so-called "North-South" debate, see Center for Concern, 3DD Memorandum \#5, RE "The outcome of the UN special session on economic issues," December $20,1980$.

2Unincorporated status includes U.S. citizenship and the application of certain fundamental aspects of the U.S. constitution, but does not allow for voting representation in Congress and voting in national elections. This limited affiliation allows a variety of future self-determined options, but in the interim significant decisionmaking, as well as approval of any future status options, rests with the U.S. Congress and with various U.S. government agencies.

3Since the U.S. purchase, the number of acres in farming declined steadily each decade from a high of 69,892 in 1917 to a low of 20,470 in 1970; see de Albuquerque and McElroy (1983b).

${ }^{4}$ According to Dookhan (1979), between 1920-22 rum exports from the USVI fell precipitously from 142,560 to 4,905 gallons. The number of ships docking declined $37 \%$, and gross tonnage dropped over 50 percent.

${ }^{5}$ Concerning these concessions, first the Organic Act of 1936 provided that U.S. exise taxes on bulk rum ( $\$ 10.50$ per gal.) produced in the territory and shipped to the U.S. be returned to the USVI to improve fiscal autonomy. In 1981 this so-called "matching fund" generated $\$ 37$ million based on exports of 3.5 million gallons. Second, USVI manufacturing exports enter the U.S. dutyfree provided that a specified portion (historically $50 \%$ and presently $30 \%$ ) of landed value is added in the territory. Third, U.S. tourist purchases of up to one gallon of liquor and $\$ 600$ in gift merchandise in the USVI are exempt from customs duties.

6In addition to the inappropriate framework, the VI Government (1980) noted other deficiencies in the two federal analyses of territorial tax performance. These included: poor economic performance during this recessionary period, stagnation in wages and salaries, two major tax reduction acts passed by Congress over this period, and several other statistical flaws which unfavorably distorted USVI revenue behavior.

${ }^{7}$ According to the USVI Congressional Delegate, a local system would be excessively expensive, politically difficult to create, and would result in reduced federal assistance; see VI Daily News (1/3/83).

8In deference to the territory's dependence on ocean freight, the so-called "Jones Act Exemption" allows USVI-US commerce in foreign rather than domestic flag ships.

9He further said that he considered the new concessions granted to the USVI watch industry (local content reduced from 50\% to $30 \%$ ) to soften the effect of increased regional competition emanating from the CBI program to be "the antithesis of the economic policies of the Reagan administration." See article, "Sanjuan: Reagan aims to wean territories" in VI Daily News (7/18/83).

${ }^{10}$ See J. McElroy (1979: 3-4). Petroleum and alumina products highly distort the USVI trade series. In 1979, the total export and import value of these two products was eleven times the value of all other trade and ten times the value of Gross Territorial Product.

${ }_{11}$ Territorial officials consider the income tax as a local revenue whereas federal officials define it as federal.

${ }^{12}$ Although the influence of other real measures of US aggregate performance (personal consumption expeditures, personal income, disposable income) was somewhat weaker, these variables were uniformly better predictors of insular employment than two local indices, GTP and estimated total tourist spending.

13The USVI Governor's Federal Budget Task Force (1981: 6) estimated 1981-83 losses of $\$ 14$ million, and the Director of the VI Internal Revenue Bureau projected another $\$ 6.8$ million between 1983-84 (VI Daily News: 7/1/83).

14Except where otherwise noted, all data support is drawn from Comparative Growth Statistics published annually by the USVI Department of Commerce and from various market surveys sponsored by that Department.

15This quote is taken from President Reagan's speech at Cancun, Mexico and reported in W.M. Will (1983: 94).

\section{REFERENCES}

Amin, S. 1974. Accumulation on a World Scale. New York: Monthly Review Press. 
Amin, S. 1976. Unequal Development: An Essay on the Social Formations of Peripheral Capitalism. New York: Monthly Review Press.

Bauer, P.T. 1981. Equality, the Third World, and Economic Delusion. Cambridge: Harvard University Press.

Beckford, G.L. 1972. Persistent Poverty. New York: Oxford University Press.

Lake, D.H. and R.S. Walters. 1983. The Politics of Global Economic Relations. Englewood Cliffs, N.J.: Prentice-Hall.

Boyer, W.W. 1983. America's Virgin Islands: A History of Human Rights and Wrongs. Durham, North Carolina: Carolina Academic Press.

Carter, J. 1980. Comprehensive Federal Territorial Policy Declaration. Washington, D.C.: Office of the White House Press Secretary, February 14.

Creque, D. 1966. The US Virgin Islands and the Eastern Caribbean. Philadelphia; Whitemore Publishing Company.

de Albuquerque, K. and J. McElroy. 1982. "West Indian Migration to the United States Virgin Islands," International Migration Review 16: 61-101.

de Albuquerque, K. and J. McElroy, 1983a. "United States Virgin Islands," pp. 636-647 in J. Hopkins (ed.), Latin America and Caribbean Contemporary Record, Vol. I: 1981-1982, and pp. 812-824 (1984) Vol. II: 1982-1983. New York: Holmes and Meier. de Albuquerque, K. and J. McElroy. 1983b. "Rural Renaissance in the US Virgin Islands," Caribbean Geography (2) 1:121-132.

Dookhan, I. 1974. A History of the Virgin Islands of the United States. London: Bowker.

Dookhan, I. 1979. "Volsteadism or National Prohibition in the United States Virgin Islands: 1917-1934," The Journal of the College of Virgin Islands (5):5-39.

Frank, A.G. 1979. Dependent Accumulation and Underdevelopment. New York: Monthly Review Press.

Henriot, P. 1979. "Development Alternatives: Problems, Strategies, Values," pp. 5-22 in C.K. Wilber (ed.), The Political Economy of Development. New York: Random House.

Hughes, A.H. 1983. "CBI: New Opportunities for American Business," Business America (August 8): 3-16.

Lewis, W.A. 1954. "Economic Development with Unlimited Supplies of Labour," The Manchester School (May): $139-91$.

Lewis, W.A. 1959. "On Assessing a Development Plan," Economic Bulletin of the Economic Society of Ghana (May-June): 2-16.

Lewis, G. 1972. The Virgin Islands: Caribbean Lilliput. Evanston, Ill.: Northwestern University Press.

Lowenthal, A.F. 1982. "Trouble in the Caribbean," Wilson Quarterly (Spr): 112-145.

McElroy, J. and J. Caines. 1980. Consumer Expenditure Patterns: A Survey of St. Thomas, USVI: 1975-76. Gainesville, Fla.: University of Florida Presses.

McElroy, J. 1979. "Trade, Food Imports, and Domestic Agriculture," USVI Economic Review (4): 3-6.

McElroy, J. "Extreme Resource Scarcity and Dependence: Virgin Islands Experience," Paper presented to the Conference on the Politico-Economic Development of Microstates. St. Thomas, USVI: Caribbean Research Institutue.

McElroy, J. 1978. "Forecasting with the Export-Base Model," pp. 73-99 in S.B. Jones-Hendrickson (ed.), Forecasting in Mircostate Economies. St. Thomas: Caribbean Research Institute.

McElroy, J. 1974. The Virgin Islands Economy. St. Thomas: Planning Office.

Miller, R. 1979. The Economy of the Virgin Islands. Washington: US Department of the Interior, Office of Territorial Affairs.

Palmer, R. 1982. "Development with Dependence: The Problem of Caribbean States," pp. 145-54 in Fanger et al. (eds.), Problems of Caribbean Development. Munchin: Wilhelm Fink.

Palmer, R. 1979. Caribbean Dependence on the United States Economy. New York: Praeger Publishers.

Rostow, W. 1960. The Stages of Economic Growth. Cambridge.

Rozynski, E. 1981. "Banking as a Vehicle for Optimal Economic Growth in the US Virgin Islands." USVI Department of Commerce, St. Thomas: Office of Policy Planning and Research.

Seers, D. 1963. "The Limitations of the Special Case," Bulletin of the Oxford Institute of Economics and Statistics 25(2): 77-98.

Streeten, P. 1966. "The Use and Abuse of Models in Development Planning," pp. 57-69 in K. Martin and J. Knapp (eds.), The Teaching of Development Economics. London: Frank Cass and Company.

Jones-Hendrickson, S.B. 1979. "An Analysis of Migration from St. Kitts-Nevis to the US Virgin Islands," Paper presented to the Latin American Studies Association, Pittsburgh, PA, April 5-7.

Tinbergen, J. 1967. Development Planning. Holland: World University Library.

Ul Haq, M. 1976. "The Third World and the International Economic Order." Washington: Overseas Development Council, Development Paper No. 22.

US Comptroller, 1978. Annual Report of the Fiscal Situation of the Government of the Virgin Islands. St. Thomas: Prestige Pres. US Department of Treasury. 1979. Territorial Income Tax Systems. Washington: Government Printing Office.

Virgin Islands Department of Commerce. 1983. Comparative Growth Statistics. St. Thomas: Office of Policy Planning and Research.

Virgin Islands Government. 1980. "IRS Extension: The Virgin Islands Position." St. Thomas: Economic Policy Council.

Virgin Islands Government. 1981. "Analysis of Impacts of Federal Budget and Tax Policies on the US Virgin Islands." St. Thomas: Governor's Federal Budget Task Force.

Waterston, A. 1974. "A Viable Model for Rural Development," Finance and Development (December): 22-25.

Will, W.M. 1983. "Reagan and the Caribbean," pp. 90-100 in J. Hopkins (ed.), Latin American and Caribbean Contemporary Record, Vol. I.

Virgin Islands Daily News

Delugo: Interior doing little for territories, (1/3/83).

Welfare grants may be cut by more than one third, (5/21/83).

Sanjuan: Reagan aims to wean territories, (7/1/83).

Quinn: Federal cuts cost VI $\$ 1.7$ million, (7/18/83). 